\title{
Article \\ Social Perception of Artificial Intelligence and Digitization of Cultural Heritage: Russian Context
}

\author{
Tatiana Leshkevich ${ }^{1}$ and Anna Motozhanets ${ }^{2, *}$
}

Citation: Leshkevich, T; Motozhanets, A. Social Perception of Artificial Intelligence and Digitization of Cultural Heritage: Russian Context. Appl. Sci. 2022, 12, 2712. https://doi.org/10.3390/ app12052712

Academic Editors: Mauro Lo Brutto and Valentina Alena Girelli

Received: 7 January 2022

Accepted: 18 February 2022

Published: 5 March 2022

Publisher's Note: MDPI stays neutral with regard to jurisdictional claims in published maps and institutional affiliations.

Copyright: (C) 2022 by the authors. Licensee MDPI, Basel, Switzerland. This article is an open access article distributed under the terms and conditions of the Creative Commons Attribution (CC BY) license (https:// creativecommons.org/licenses/by/ $4.0 /)$.
1 Department of General and Pedagogical Psychology, Academy of Psychology and Educational Sciences, Southern Federal University, 344006 Rostov-on-Don, Russia; leshkevicht@mail.ru

2 Department of the English Language for Humanities, Institute of Philology, Journalism and Intercultural Communications, Southern Federal University, 344006 Rostov-on-Don, Russia

* Correspondence: annamt@bk.ru

\begin{abstract}
The article considers the social perception of artificial intelligence (AI) as an essential factor having an impact on the digitization, transfer, and popularization of cultural heritage. The article aims at the theoretical comprehension of the digital ontology and implementation of AI in the context of Russian realia. The research relies on comprehensive analysis based on statistical data, using descriptive and comparative methods. The interdisciplinary approach adopted includes reflexive analysis of both positive and negative consequences of the digitalization process. The article examines the peculiarities of the "digital ontology", deterritorization effect, new actors in the digital process, the effect of digital trust, and opposite views of AI-enthusiasts and AI-alarmists. The article describes objective and subjective reasons for the negative perception of digital artifacts, and states the need to consider the influence of key figures in digital ontology: influencers, stakeholders, and data scientists. The ambivalence of public perception of both artificial intelligence and digital cultural heritage is stated. The research reveals digitization frontiers, which involve three factors: the axiological factor, indicating the need for consistency between a human values system and AI development programs; the subject vector, emphasizing the role of a new type of digital heritage bearers and digital influence actors; ethical factor associated with the need to transform relations with information technologies in order to subordinate them to human reflection and comprehension. The authors conclude that cultural heritage digitization should be aimed at generating a human-centered future.
\end{abstract}

Keywords: digital heritage; artificial intelligence; social perception; "digital ontology"; ambivalence

\section{Introduction}

Social perception of artificial intelligence (AI) is an essential factor defining the use of AI applications for digitizing and popularizing cultural heritage. The process of interacting with the latest technologies has become an object of assessment, attesting to the fact that theoretical developments have entered the practical implementation phase. Researchers consider it necessary to track users surfing the net, visiting interactive installations, and exploring the designed space. It is essential to define web pages that are most relevant to a particular search query and to analyze which links offered for the same search query have been earlier clicked by a user [1]. Thus, the user-constructed media act becomes an important indicator of digital product acceptance.

Aimed at maximizing social benefits, AI applications embrace various areas of our life, including the service industry, in security, trade, and management. Digital libraries, museums, cinemas, concert halls, scientific and educational organizations, discussion platforms, an all-knowing digital information desk, etc. [2], are of particular importance in the process of transferring cultural values. Human interaction with digital technologies has become a marker of the 21st century, and it is not only technological revolution that these ongoing shifts indicate [3]. Russian scholars view such an intense impact of digital technologies and 
AI on humans and humanity as a humanitarian-technological revolution [4]. The intensive expansion of AI systems leads to transformations in the conceptual sphere of modern existence [5]. In the framework of the "Culture" national project in Russia, 500 virtual concert halls have been established, 450 digital guides on the best exhibition projects have been created, and 448,000 literary monuments and museum exhibits have been digitized. By 2024, the number of visits received by digital cultural resources is expected to increase by five times, and the budget costs will amount to 84 million rubles [6].

Digital interactions are believed to be a completely new experience for the human CNS (central nervous system), which alters brain activity patterns and causes a stimulating effect [7]. The principle of plasticity has been accepted in modern biological and medical sciences. It states the ability of neural networks to change and adapt under the influence of experience and other external and internal factors [8]. Scholars discuss the phenomena of visual thinking and visual selective attention: visual environment shapes the skill of simultaneous (non-linear) perception, which means the ability of "grasping" the whole image rather than focusing on details successively [9]. Russian researchers claim that "smart" devices are perceived as intelligent partners with transactive memory, which enables one to store information on external media. The ability to focus on a visual object regardless of the level of the perceptual environment, i.e., despite "pollution", is also discussed [10]. Since the Internet and digital technologies are seen as a transactive memory resource [11], the process of cultural heritage digitization with its memorization effect becomes particularly relevant for the further development of humankind.

The need to include the category of the "digital" and information technologies in the scope of social and humanitarian research has long been emphasized by some scholars [12], with Russian authors taking an active part in the discussion [13]. The debate on the need to institutionalize the "digital cultural heritage" was further fueled by the discussion of the lack of uniform standards for its digitization [14]. Researchers reveal interdependence between digitalization and softwarization, i.e., dependence upon software and its influences. Software is believed to shape the space, while the so-called "old cultural environment" (films, museums, printed press) becomes the content of the digital heritage [15]. It should be emphasized here that digital cultural heritage includes both digital versions of analogue cultural objects and artifacts originally created in a digital format. According to researchers, these two components are represented by digitized exogenous data and digital endemic data. The endemic digital content includes simulators, quests, educational products, information data [16], as well as multimedia products, hypermedia, online dialogue, and mobile content. In this regard, software is no longer viewed as a code or a computer program, but more of a cultural object or "a dimension of cultural space" that provides access to cultural heritage and redistributes cultural practices [17]. At the same time, digitally born objects may refer to either fixed born digital or dynamic born digital [18].

Negative aspects of digitizing and popularizing cultural heritage should also be considered. For example, digital artifacts are believed to be characterized by the following feature: the more meaningless the content, the more the online action tends towards visual impact [19]. Attention is drawn to the difficulty of access to online resources for reasons of both objective and subjective nature. The former include software and hardware problems, high hardware costs, the lack of free or low-cost access, and intellectual property restrictions. The latter include the lack of digital skills and the lack of experience in using national and foreign information systems [20]. Researchers discuss new forms of vulnerability related to the problems of online fakes and "filter bubbles" [21]. This being a complex, multi-faceted issue, our article aims at a holistic theoretical comprehension of digital ontology with regard to using AI for popularizing cultural heritage in the context of Russian realia.

The adopted methodological strategy includes factor analysis that reveals four types of human-AI interaction. These involve the expanded ("human intellectual support") and limited ("human prerogative") use of intelligent systems, as well as an applied aspect of AI connected with facilitating "routine operations" or operations aimed at solving "applied problems" [22]. Descriptive and comparative methods are used. We cannot fail to agree with 
scholars who emphasize the interdisciplinary nature of this area, comparing it to a "melting pot" of various technologies [23]. It is necessary to point out here that researchers involved in the analysis of technologies note that cultural heritage digitization relies on the so-called cross-reality (XR) technologies to represent objects of historical, scientific, and artistic interest. They highlight the efficacy of augmented reality (AR), including the reconstruction of architectural and environmental heritage, exhibition data management, presentation, and storytelling. However, more importantly, this specific augmented reality experience reveals the value of a cutting-edge VV (motion capture) technology to create a digital guide that would "add flavor" to museum visitors' museological experience [24]. Along with specific technological methods, attention should be given to an integral approach, which draws together the digital environment as a part of the cognitive system and the cognizing subject located in it [25].

Interdisciplinary analysis reveals statistical data that attest to a growing audience absorbed by screen culture. According to statistics, by the beginning of 2021 the number of Internet users worldwide had increased to 4.54 billion, which is $7 \%$ higher than the last year's estimates (298 million new users in comparison with the data for January 2019). According to the Digital 2020 report, the number of internet users in Russia amounted to 118 million in 2020. An average Russian spends $7 \mathrm{~h} 17 \mathrm{~min}$ online every day [26]. Figures are different for different age and gender groups: young people spend more time on the Internet than the older generation, and women spend less time than men. At the beginning of 2020, Instagram's advertising audience in Russia amounted to 44 million people, equal to $36 \%$ of the country population. Moreover, according to App Annie, smartphone users have downloaded over 200 billion mobile apps in the past 12 months, having spent a total of $\$ 120$ billion on apps and in-app purchases [26]. Klaus Schwab predicts the following changes by 2025: 1 trillion sensors connected to the Internet; the first commercially available implantable mobile phone; $10 \%$ of people wearing clothes connected to the Internet; $90 \%$ of the population having regular access to the Internet [27]. All the above-said attests to ongoing transformations in the ways of transferring cultural heritage and a new digital dimension of culture.

It is worth noticing that modern authors highlight a significant role of digital humanlike characters in virtual worlds, both as counterparts of real human users and as embodied agents driven by artificial intelligence. They justify the use of virtual people in a variety of applications, focusing on four areas: environmental design, education, cultural heritage, and healthcare [28]. However, the idea that gave rise to a relevant "avatar problem" is at least two centuries old, and can be found in the works by M. Shelley "Frankenstein, or Modern Prometheus" and "The Last Man" [29]. It was also used in S. Butler's "Erewhon" (1872), where the name is an anagram from "Nowhere". It should be emphasized that the idea of bio-technological convergence appeared in popular science books by Russian scientists. For example, I.M. Rosokhovatsky wrote popular science books in collaboration with A. A. Stogniy, a cybernetic scientist, the Doctor of Physical and Mathematical Sciences, corresponding member of the USSR Academy of Sciences. Among them are: "CD—Cybernetic Twin" and "The Designer Vasilchenko Double" [30]. Examples are numerous. Obviously, the tendency has turned to a dominating trend. Within a new technological paradigm, the focus is shifted to new digital media, to the digital way of existence and popularization of cultural heritage, the replacement of physical reality with its analogue-digital projection. The pandemic has triggered radical changes in the cultural code transfer.

\section{Digital Ontology: “Digital" Heritage vs. “Living” Heritage}

With digital technologies becoming an integral component of modernity, the following philosophical issue arises. On the one hand, the values and norms of modern existence should be related to actual physical "being", but on the other hand, they should be correlated with new technological changes opening up vast prospects for digitizing the entire cultural heritage of humankind. While in pre-pandemic times, this situation used to be described as belonging simultaneously to two worlds of online and offline interactions [31], 
nowadays the new technological paradigm and pandemic-related challenges are generating a world dominated by $\mathrm{AI}$ and digital determination. Affecting all types of interactions, digitalization creates a new digital culture bearer and new layers of sociality, in which a person is not physically present. Access to the digital world is associated with digital competencies. Today, expanding experience means the ability to navigate the digital algorithms. An adequate response to the challenges of the time will involve "building digital muscles". "No spatial movement!" is a new imperative, which means that anything can be done, learned, or ordered online. A computer or smartphone opens the door to the World Wide Web [32].

According to Yuk Hui, "digital ontology", which has largely become a sphere of modern existence, is a corpus of organized data that can take visual, sound, or textual form, as a unity consisting of multiple formal properties [33]. A digital object is represented by a code and a displayed image on the screen of a monitor or a gadget. Researchers claim that our computer-based activity relies on mathematical operations, which have their fundamental limitations that define the boundaries of technologies [34]. It should be emphasized here that digital heritage is characterized by the absence of material form, in other words, it exists in virtual space. The perception of digitized objects represents a transempirical transfer of experience and generates a specific mode of influence on a personality psycho-mental structure. The real object is replaced by its virtual counterpart, claiming ontological equality and ignoring specific physical spatiotemporal interactions. Virtual, or "derived", reality becomes a generative ("primary") one. In fact, we can now witness a transition to symbolic forms of maintaining sociality, which are not directly connected to the material and physical existence.

This situation can be characterized by J. Derrida's concept of the "absent presence" [35]. This can be illustrated by a link to the burnt-down Notre-Dame de Paris: it exists in a form of a digitized object which nevertheless cannot replace the original. Thus, technological substitution, which aims to compensate for the absent object, does not remove the question of its authenticity. Moreover, the sustainability of the digital legacy remains doubtful due to its dependence on software that may turn out to be vulnerable, outdated, or deteriorate.

At the same time, when discussing global "digital ontology", one should highlight deterritorization and amplification effects. The former leads to blurring geographical borders as well as the boundaries of social interactions between states, educational spaces, and public and private spheres of life. Another feature defined by the term "amplification" is connected with generating an infinite number of copies, which allows for the arbitrary treatment of time and sequences of events within the digital domain [36]. However, questions arise concerning whether the impact of a digital copy is equivalent to that of a real object; if digitized heritage can be viewed as equivalent to a tangible heritage that is meaningful and reflected on; if screen culture leads to significant cognitive deformations, and we have to admit that social memory starts being influenced by technological algorithms rather than humanitarian and reflexive needs.

A critical analysis of digitalization reveals that in the digital world material objects have the status of a "stage" or "scenery" for social interactions [37]. In contrast to "live" perception, screen and computer interactions simplify imagination. This is confirmed by some research findings, according to which media information technologies have a negative impact on imagination, leaving neither space nor stimulus for creativity [38]. Information overload impairs concentration, which is seen as a "gateway" between information flow and the brain [39]. According to scientists, digital overload can lead to a techno-brain burnout [9]. According to Russian scholars, cyber addiction undermines information processing skills and impairs concentration [40]. So-called "clip" thinking is viewed as a defensive reaction to information overload [41]. Cognitive skills cannot be replaced by "clip" (tag) thinking, which is a derivative of continuous Net surfing. Studies show that clip thinking disrupts a person's ability to perceive integrity, cause-effect relationships, and make generalizations. Fragmentary clip-like consciousness is akin to an affective impulse aimed at quick thinking rather than thorough reflection [42]. 
The "Clicking Man" or "Homo Zapiens" (from "zapping", i.e., switching channels) values non-contact communication, i.e., voice-control switching, using a clock timer, machine vision technology, etc. Moreover, digital interaction substitutes reading for skimming, skipping the "unnecessary" information. All this attest, firstly, to the imbalance between the qualitative and superficial modes of comprehending the meaning of the world cultural heritage. Secondly, it reveals the ambivalent attitude to the digitized cultural heritage.

\section{Social Perception of AI: Key Factors}

The pandemic has contributed to the transition of all communication types to online platforms, which offer an increasingly flexible network architecture. Against this background, the discussion of the impact caused by AI in the process of digitizing cultural heritage should begin with the problem of defining AI itself. In this regard, two main approaches should be highlighted: AI as an area of research and AI as a set of technologies [43]. The lack of a clear definition of AI seems to be accepted and justified by scholars. One of the most succinct definitions states that $\mathrm{AI}$ is a technical system that is used for problem solving [44]. A more detailed definition describes a structure involving: (Knowledge base + Fact base) + Problem solver + Intelligent system interface [45]. Researchers do not consider Narrow AI to be intelligence in the full sense of the word. Rather, it is a higher level of labor automation [46]. At the same time, the so-called Narrow AI can be useful to a large extent, since it relies on models with verifiable optimality. Significant features of interactivity include controllability, synchronicity, and bidirectionality [47].

Among different ways of perceiving digitized cultural heritage, one can find a neutral, non-evaluative attitude, stating "the multi-level landscape of modernity shaped by the latest emerging technologies" [48]. A positive social perception of AI is driven by smart assistant applications with enhanced interactivity. In 2019, about 3.25 billion people around the world were reported to have used digital assistants, and by 2023 their number is expected to reach 8 billion [47]. According to forecasts by the Huawei corporation, there will be over 40 billion personal smart devices worldwide by 2025 , and $90 \%$ of device users will have smart digital assistants. At the same time, applications will be constantly improving and updating. Examples of "smart" assistants are modern systems of software agents that track users' search queries, what they read, films they watch, music they listen to, etc., and offer new options that match users' interests. More sophisticated software agents can track online auctions, bids, and sales. Thus, software agents seem to become a part of the subject rather than a problem-solving tool. A person begins to trust them entirely [49], which illustrates a technological symbiosis between a biological user and software agents.

Another example is "intelligent conversational agents". However, experts note that contemporary AI systems are not good at maintaining a long dialogue. Problem solving with modern "conversational systems" consists of three stages: understanding the request, managing the dialogue, and acting, i.e., providing an answer. The system must understand the utterance, identify the user's intentions, and classify the request by analyzing the text for task parameters. Developing dialogue systems is one of the most challenging tasks, especially in the case of an open dialogue. According to researchers, conversational systems are now capable of discussing short text fragments from Wikipedia and maintaining personalized small talk [50]. Chatbots can maintain a conversation on general topics: hobbies, work, family, pets. There is also Persona-Chat technology. However, quality conversations between humans and bots are still very rare. Of interest is the open source DeepPavlov library [51] for creating chat bots, text analysis and virtual assistants with focused dialogue skills and a chatter, which is used in 80 countries.

Experts agree that machines will have to respond to various types of environmental signals, with human speech being the most significant one. Moreover, they must be able to respond to warnings, understand and follow instructions given by humans, and interpret them correctly. AI now copes with modeling strict human reasoning, relying on the system of postulates and the means of logical inference. However, machine learning associated 
with extracting useful and adequate knowledge from experimentally demonstrated facts and training examples is still problematic. Mathematically, it is impossible to program a machine so that it can maintain a full-fledged human dialogue. It is also noted that models that recognize two-dimensional images "have no idea" that those images are actually projections of a three-dimensional world. It is still unclear how to teach computer vision models that the world is three-dimensional [52].

The social perception of AI, which is involved in the process of digitizing cultural heritage, is greatly influenced by the degree of consistency between the value system and the way it is reflected in AI programs. This raises a number of questions. How well does the act of "value classification" fit into the algorithm? Which goals and values should be embedded in AI? According to the 2019 Presidential Decree, the goals for the development of artificial intelligence in Russia are of humane character and include: increasing welfare and improving social indicators, ensuring national security and legal order, and achieving sustainability of the Russian economy, including leading positions in the field of AI [53]. According to the National Strategy for the Development of Artificial Intelligence for the Period up to 2030, artificial intelligence is understood as a set of technological solutions that simulate human cognitive functions, including self-learning, finding solutions without a predetermined algorithm, and obtaining results comparable with the results of human intellectual activity [53].

Experts note that $\mathrm{AI}$ is already being used in Russia to solve a variety of problems. If human-AI interaction is perceived as a friendly partnership, AI development strategies should include some restrictions. The "value matrix" incorporates human attitudes into the objective world and major events. Semantics of the concept of "value" emphasize high-quality choices and meaningful claims related to actual sociocultural space. Scholars point to the need to avoid threats to any stakeholders' values [54]. Otherwise, the outflow of users of certain programs and applications is predicted.

However, a question arises concerning whether compliance with the values is a feasible task for AI systems. The issue of embedding value-ethical norms and principles in AI systems, which will guide their practices, becomes particularly acute. In this regard, researchers describe three implementation models. The first one includes settings predefined by the software developers' choices. The second one involves imitative self-learning programs that shape values and orientations based on interaction with the environment and other agents. The third model extrapolates values and ideal ethical attitudes based on generalized collective social choice decisions [55]. Emphasizing that intelligent systems developers should comply with ethical standards, Russian scholars articulate three acute problems. The first one deals with the constructive formalization of ethical norms in a form that could be described and accepted by software and hardware systems. The second problem is connected with the objective possibility to monitor the compliance using intelligent information system components with ethical standards. The third problem is that developing ethical standards has a restrictive function and can thus slow down intelligent systems development, which in turn may lead to the standardization and subsequent certification of intelligent systems [56]. Another issue that needs to be emphasized here is that software products which are actively used in the process of digitizing cultural heritage should focus on creating a coherent future environment.

\section{Digital Influencers, Stakeholders and Data Scientists}

Within the UNESCO framework, it was decided to support the network interaction of the so-called fact-checkers, the digital space actors engaged in selecting and distributing trustworthy information and resisting "information phantoms" [18]. This group also includes innovative types and active players of the digital world, e.g., stakeholders, data scientists (Big Data integrators), and influencers having significant social influence in the digital world.

Influencers are seen as opinion-leaders having a special impact on the audience. Their preferences largely determine which software product will be successful and which will be 
a failure. As a rule, influencer's attitudes are pragmatic-oriented. The goal is to promote the advantages of this or that technology occupying a certain niche. Thus, it can be concluded that influencers represent a certain type of subject generated by the digital environment and combining self-expression on the Web with the promotion of a particular software product. They aim is winning the audience. Of particular importance is an influencer-expert who is a specialist in the field and shares professional knowledge.

Another type of subject that is significant in the applied use of AI in the selection and digitization of cultural heritage is represented by stakeholders, who can influence the decision-making process in system engineering. The main criterion is their role in the project. Stakeholders' activity is determined by their decisions [57]. Since each system has its own life cycle, including the stages of design, development, production, implementation, operation, and disposal, the variety of functions stakeholders perform depends on the particular stage they administer and prioritize. Quite often, the status of a stakeholder is not predetermined, but is defined in the process of decision-making. Stakeholders become a part of competition between various innovative technologies in order to ensure preference for those that are announced as the most promising ones. It should be noted that there are "positive" and "negative" stakeholders that implement corresponding practices.

Another figure that plays a significant role in launching "digital cultural heritage" projects is a "data scientist", a big data integrator and interpreter. Data scientists provide undeniable arguments for certain decisions based on big data. In Russia, this type of work is becoming more and more popular, since the intensive development of AI creates new jobs for the specialists. However, modeling complex objects requires collecting and processing huge amounts of data as well as computational and energy resources, which may be hard if not impossible. For that reason, solutions offered by data scientists are sometimes considered inexplicable and treated negatively.

In today's fast-paced world, this negative attitude towards big data-based decisionmaking is reflected in the term "dataism". According to Yuri Harari, data scientists view the entire human race as a data processing system, with each person being its microprocessor. Dataism relies on the following principle: a dataist should want to maximise dataflow by connecting to more and more media. "Obey the algorithm" is the dataist motto [58]. Thus, the actual process of cultural heritage digitization together with the key figures of digital ontology define new subject types: fact checkers, influencers, stakeholders, and data scientists.

\section{AI-Alarmists vs. AI-Enthusiasts}

The social perception of the digitized cultural heritage is influenced by two opposing worldview positions: AI-enthusiasts and AI-alarmists. AI-alarmists are worried about the prospects of algorithmic domination, the forced impact of digital determination with its simulative effects that distort the image of the world [59]. There are concerns about the fact that powers and competencies may be transferred from humans to network algorithms, and human neuronal activity may become vulnerable to intrusions. Possible effects of pathological internet use, which can cause deviations and maladaptive behavior, are also seen as a threat. Moreover, the risk of cognitive degradation in humans associated with delegating intelligent tasks to machines causes concerns [60].

A report by the AI Now Institute at New York University (December 2018) emphasizes the two most pressing problems: the deepening inequality between those who can use AI technologies and those who cannot and the consequences of mistakes for those who become their victims [61]. When discussing the existing "epistemological opacity", researchers note that in spite of being preprogrammed, many of the AI systems turn into a "black box", i.e., the type of regularity or correlation between the input and the output is not entirely clear. While in some cases it may be based on a simple statistical correlation, in others it may rely on a causal connection [62]. According to J. Barratt, given the existing power and complexity of technologies, there are concerns associated with the unpredictable behavior of AI systems. This unpredictability will be combined with random incidents that result from 
the complexity of the device [63]. Timely risk assessment associated with developing AI is highly prioritized [64]. Real threats may include program errors that software developers may be unaware of, and the fact that AI can work against programmers' intensions, making wrong decisions in critical situations. It is no coincidence that the digital age is described as the age of software that can run into problems. The term "glitch" indicates a technical failure [65]. Software developers testify to the fact that it takes a lot of time and effort to reveal the "affected area", to debug the program and fix errors [66,67].

However, the "malicious" misuse of AI is particularly disturbing. It is classified by territorial coverage (local, regional, global), by the degree of damage caused (minor, significant, large, catastrophic), by spreading rate (slow, fast, rapid), and by the form of spreading (open, hidden) [68]. It is worth noticing that the Club of Rome report on the challenges of digitalization reveals that all positive things related to information and digital technologies cause negative effects of the first order, when considering their direct consequences in terms of sustainability [69]. At the same time, scientists consider the discussion about the threats of integrating modern technologies in our lives to be at least five years behind the real state of affairs [70]. Of course, all this cannot but affect the social perception of AI, even if it is generally seen as friendly and trustworthy.

At the same time, when AI-enthusiasts argue for the advantages of AI, the first thing that is mentioned is the ability to quickly find optimal solutions to problems with fixed boundaries and predetermined criteria. If the boundaries of the model are clearly set and goals are defined, AI solves these problems better than a human. Delegating routine work to AI will free huge intellectual resources for humankind. Comparing "human" and "computer", physicists come to a similar conclusion. Expressing his humanitarian outlook on the problem, M. Kaku claims that AI technologies are human-friendly and the superiority of their intellectual power over the human brain cannot be immoral [71]. Studying the effect of human "extension" through technological development, E. Clark proves that the human-technology symbiosis is a natural phenomenon [72]. At the same time, the extension of human capabilities through technologies can only become possible if the integration of technologies with the existing biological capacities is smooth. Moreover, technologies are sensitive to the users' needs, constantly adapting and aiming at their satisfaction.

\section{Results and Conclusions}

Under modern conditions, the process of digitizing cultural heritage has revealed its paradigmatic character. However, it is connected with a number of negative features. In addition, the implementation of digitization tools largely depends on users' preferences and social perception. This shifts attention to the interrelationship between digitalization and softwarization and highlights the problem of the institutionalization of digital cultural heritage, which is especially relevant in the context of Russian realia. Since digital heritage is characterized by the absence of material form, i.e., it exists in virtual space, the research reveals ambivalence in its interpretation. Firstly, it refers to digitization of the already existing analogue resources, when the so-called "old cultural environment" becomes the content. Secondly, it may refer to artifacts that were originally created in digital format, i.e., "digitally born". They may be either static (fixed born digital) or dynamic, and can be accompanied by simulators, quests, and interactive hypermedia. Among the objective reasons for the negative perception of digital artifacts are the following: the lack of easy access to the Net, high software and hardware costs, their complexity, and possible failures. The sustainability of digital heritage, as well as the protection of intellectual property, may also become an issue. Subjective reasons include the lack of digital skills and a widespread tendency consisting in the fact that the more primitive the content, the more visual effects it relies on. New forms of vulnerability are also represented by "fakes", "filter bubbles", "information phantoms".

The analysis of opposing views by AI enthusiasts and AI alarmists support the idea of ambivalence in perceiving digital technologies and embraces ontological, anthropological, 
and technological-functional dimensions. AI alarmists express concern about the prospects of forced submission to a digital algorithm and digital determination with its simulative effects. Anthropological projection reveals the risk of cognitive degradation, when mental effort is delegated to a machine, "clip" thinking, devoid of the sense of integrity and cause-effect relationships. The problem of the digital divide is also discussed. From a technological-functional perspective, concerns are expressed as to the consequences of mistakes for those who become their victims; complexity and non-transparency of technologies, errors, failures, and system glitch. A particular risk is related to the cases of AI misuse, which may be either minor or massive, slow, or dynamic.

AI enthusiasts, on the contrary, emphasize the ability to find quick and effective solutions to problems with pre-set boundaries and predetermined criteria; to delegate routine work to AI and redirect intellectual resources of humankind. Attention is focused on the effect of human "extension" through technological development and meeting users' needs. "Smart" devices are seen as intelligent partners, including those with transactive memory, and human-AI partnership is classified as a friendly one.

Analyzing a new digital dimension of a culture bearer, we conclude that strategic goal-setting should be based on the need to preserve the reasonable person rather than a pragmatic aspect of technological development. Cultural heritage digitization should be aimed at generating a human-centered future. An interdisciplinary synthesis, within which technological development is accompanied by a theoretical and reflexive analysis of both positive and negative consequences, is prioritized.

We believe that significant frontiers of cultural heritage digitization include, firstly, the axiological factor, indicating the need for the coherence between the system of human values and the programs for AI development and use. At the same time, it is emphasized that values, on the one hand, are related to physical existence. However, on the other hand, should be in line with innovative technological capabilities. Preserving the value system is seen as a priority that will help retain users.

Secondly, attention should be given to the subject vector, emphasizing the role of a new type of digital actors-fact-checkers, influencers, stakeholders, and data scientists. Influencers are opinion leaders who promote software products. Their preferences define the success of a particular software product. Stakeholders can influence the decisionmaking process in system engineering. They become a part of competition between new technologies in order to ensure preference for those that are announced as the most promising ones. "Data scientist" as an integrator and interpreter of big data comes in the foreground when cultural digital heritage projects are launched, rationalizing certain decisions on the basis of big data.

Another factor that should be highlighted is the ethical one associated with the need to transform relations with information technologies in order to subordinate them to human reflection and awareness. The prioritized scenario focuses on universal civilizational well-being, articulated by the slogan: "Machines must work, people must think"!

Author Contributions: Conceptualization, T.L. and A.M.; methodology, T.L.; software, A.M.; validation, T.L. and A.M.; formal analysis, T.L.; investigation, T.L.; writing-original draft preparation, T.L.; writing-review and editing, A.M.; supervision, T.L.; project administration, T.L. All authors have read and agreed to the published version of the manuscript.

Funding: This research is funded by Academy of Psychology and Educational Sciences, Southern Federal University, Rostov-on-Don, 34006 Russia.

Institutional Review Board Statement: Not applicable.

Informed Consent Statement: Not applicable.

Data Availability Statement: Not applicable.

Conflicts of Interest: The authors declare no conflict of interest. 


\section{References}

1. Manovich, L. Как следовать за пользователями программ? [How to Track Programm Users?]. Available online: https: / / cyberleninka.ru/article/n/kak-sledovat-za-polzovatelyami-programm/viewer (accessed on 25 January 2022). (In Russian)

2. Zaks, L.A. K исследованию аксиологии Интернета [On Axiology of the Internet]. Available online: https:/ / elar.urfu.ru/ bitstream/10995/41362/1/iuro-2016-155-03.pdf (accessed on 25 January 2022). (In Russian)

3. Leshkevich, Т. Феномен цифрового отчуждения [The Phenomenon of Digital Alienation]. Available online: https: / / cyberleninka.ru/article/n/fenomen-tsifrovogo-otchuzhdeniya/viewer (accessed on 23 January 2022). (In Russian)

4. Malinetskiy, G.G. Цифровая реальность в точке бифуркации и стратегические задачи Союзного государства в контексте гуманитарно-технологической революции [Digital Reality at the Point of Bifurcation and Strategic Tasks of the Union State in the Context of the Humanitarian and Technological Revolution]. Available online: https://keldysh.ru/future/2019/2.pdf (accessed on 4 January 2022). (In Russian)

5. Leshkevich, T.; Motozhanets, A.; Kataeva, О. Цифровая детерминация и трансформации смысложизненной рефлексии [Digital Determination and Transformations in Life-Meaning Reflection]; Simon Fraser University: Rostov-on-Don, Russia, 2020.

6. Национальный проект культура [Culture National Project]. Available online: https://www.roskultproekt.ru/razdel1 (accessed on 25 December 2021). (In Russian)

7. Small, G.W.; Moody, T.D.; Siddarth, P.; Bookheimer, S.Y. Your brain on Google: Patterns of cerebral activation during Internet searching. Am. J. Geriatr. Psychol. 2009, 17, 116-126. [CrossRef] [PubMed]

8. Weidel, M.; Heikkinen, K. Developing Minds with Digital Media: Habbits of Mind in the YouTube Era. Available online: https:/ / numerons.files.wordpress.com/2012/04/17developing-minds-with-digital-media.pdf (accessed on 22 January 2022).

9. Small, G.; Vorgan, G. iBrain: Surviving the Technological Alteration of the Modern Mind; Harper Collins: New York, NY, USA, 2009.

10. Golubinskaya, А. Нейрокогнитивный подход к исследованию поколения z [Neurocognitive Approach to Generation Z Research]. Available online: https://cyberleninka.ru/article/n/neyrokognitivnyy-podhod-k-issledovaniyu-pokoleniya-z/ viewer (accessed on 22 January 2022). (In Russian)

11. Henkel, L.A. Point-and-shoot memories: The influence of taking photos on memory for a museum tour. Psychol. Sci. 2014, 25, 396-402. [CrossRef] [PubMed]

12. Ruppert, E.; Law, J.; Savage, M. Reassembling Social Science Methods: The Challenge of Digital Devices. Theory Cult. Soc. 2013, 30, 22-46. [CrossRef]

13. Mozhaeva, G.V.; Mozhaeva-Renha, P.N.; Serbin, V.A. Цифровая гуманитаристика: организационные формы и инфраструктура исследований [Digital Humanities: Organizational Forms and Infrastructure Research]. Available online: https:/ / cyberleninka.ru/article/n/tsifrovaya-gumanitaristika-organizatsionnye-formy-i-infrastruktura-issledovaniy-1 (accessed on 4 January 2022). (In Russian)

14. Gorlova, I.I.; Alexander, L.Z.; Kryukov, A.V. Conceptualisation and Institutionalisation of the Concept "Digital Cultural Heritage". Available online: https:/ / www.researchgate.net/publication/338992714_Conceptualisation_and_Institutionalisation_of_the_ Concept_Digital_Cultural_Heritage (accessed on 3 January 2022).

15. Zhuravleva, Е.Y. Софтверизация общества: истоки и перспективы [Softwarization of Modern Society: Origins and Prospects]. Soc. Stud. 2019, 4, 109-117.

16. Krylasov, A.V. Представление нематериального культурного наследия в киберпространстве [Representation of Intangible Cultural Heritage in Cyberspace]. Available online: https://www.elibrary.ru/download/elibrary_44507226_71325356.pdf (accessed on 2 January 2022). (In Russian)

17. Manovich, L. Software Takes Command; Bloomsbury Academic: London, UK, 2013.

18. Spivak, D.L. Цифровизация в культурной стратегии ЮНЕСКО [Digitalization in the Cultural Strategy of UNESCO]. Available online: https://www.elibrary.ru/download/elibrary_44507226_89995248.pdf (accessed on 4 January 2022). (In Russian)

19. Gvozdikov, D. Схоластика для инстаграма: к цифровой антропологии современности [Scholastica for Instagram: Towards Digital Anthropology of Our Time]. Available online: https:/ / cyberleninka.ru/article/n/sholastika-dlya-instagrama-k-tsifrovoyantropologii-sovremennosti/viewer (accessed on 3 January 2022). (In Russian)

20. Shapovalova, G.M. Online Environment of Digital Cultural Heritage: Informational and Legal Aspect. Available online: https: / / www.elibrary.ru/download/elibrary_26281355_28912637.pdf (accessed on 26 November 2021). (In Russian)

21. Gurov, P.N. Опыт социально философского осмысления проблемы «фейков» и «пузырей фильтров» в Сети [The Ехрегіеnсе of Social and Philosophical Explanation of the Problem of "Fakes" and "Filter Bubbles" on the Web]. Available online: https:// cyberleninka.ru/article/n/opyt-sotsialno-filosofskogo-osmysleniya-problemy-feykov-i-puzyrey-filtrov-v-seti/viewer (accessed on 3 January 2022). (In Russian)

22. Pinchuk, A.N.; Tikhomoriv, D.A. O взаимодействии человека и искусственного интеллекта: новая социальная реальность в представлении московских студентов [On the Interaction of Human and ARTIFICIAL intelligence: A New Social Reality in the Minds of Moscow Students]. Available online: https:/ / cyberleninka.ru/article/n/o-vzaimodeystvii-cheloveka-i-iskusstvennogointellekta-novaya-sotsialnaya-realnost-v-predstavlenii-moskovskih-studentov/viewer (accessed on 4 January 2022). (In Russian)

23. Arnold, D.; Day, A.; Glauert, J.; Haegler, S.; Jennings, V.; Kevelham, B.; Laycock, R.; Magnenat-Thalmann, N.; Maïm, J.; Maupu, D.; et al. Tools for Populating Cultural Heritage Environments with Interactive Virtual Humans. Available online: http:/ / publicrepository.epoch-net.org/rome/03\%20Tools\%20populating\%20CH\%20Environments.pdf (accessed on 20 January 2022). 
24. O'dwyer, N.; Zerman, E.; Young, G.W.; Smolic, A.; Dunne, S.; Shenton, H. Volumetric Video in Augmented Reality. Applications for Museological Narratives. J. Comput. Cult. Herit. 2021, 14, 1-20. [CrossRef]

25. Myachykov, A.; Scheepers, C.; Fischer, M.H.; Kessler, K. Test: A tropic, embodied, and situated theory of cognition. Top. Cogn. Sci. 2013, 6, 442-460. [CrossRef] [PubMed]

26. Sergeeva, J. Вся статистика интернета на 2020 год-цифры и тренды в мире и в России [All Internet Statistics for 2020Numbers and Trends in the World and in Russia]. Available online: https://www.web-canape.ru/business/internet-2020 -globalnaya-statistika-i-trendy/ (accessed on 4 January 2022). (In Russian)

27. Schwab, K. The Fourth Industrial Revolution. Available online: https://law.unimelb.edu.au/_data/assets/pdf_file/0005/33854 54/Schwab-The_Fourth_Industrial_Revolution_Klaus_S.pdf (accessed on 2 January 2022).

28. Carrozzino, M.A.; Computer, R.G.I. Do Virtual Humans Dream of Digital Sheep? IEEE Comput. Graph. Appl. 2020, 40, 71-83. [CrossRef] [PubMed]

29. Shelley, M. Frankenstein; The Modern Premetheus. The Last Man; Nauka, Ladomir: Moscow, Russia, 2010. (In Russian)

30. Rosokhovatsky, I.M.; Stogniy, A.A. CD—Cybernetic Twin; Naukova Dumka: Kiev, Ukrain, 1975.

31. Drozdova, A.V. Концептуализация повседневности в эпоху цифровой культуры [Conceptualization of Everydayness in the Epoch of Digital Culture]. Available online: https:/ / www.elibrary.ru/download/elibrary_35246025_94425485.pdf (accessed on 20 January 2022). (In Russian)

32. Leshkevich, Т. Цифровые трансформации эпохи в проекции их воздействия на современного человека [Digital Transformation of the Era in the Projection of Their Impact on the Modern Man]. Available online: http://journals.tsu.ru/uploads/import/ 1809/files/439_103.pdf (accessed on 4 January 2022). (In Russian)

33. Hui, Y. On the Existence of Digital Objects; University of Minnesota Press: Minneapolis, MN, USA; London, UK, 2016.

34. Broussard, M. Artificial Unintelligence: How Computers Misunderstand the World; MIT Press: Cambridge, MA, USA, 2018.

35. Derrida, J. Призраки МарксаГосударство долга, работа скорби и новый интернационал [Specters of Marx: The State of the Debt, the Work of Mourning \& the New International]. Available online: https:/ / predanie.ru/book/217532-prizrakimarksamarks-i-synovya/ (accessed on 22 November 2021). (In Russian)

36. Leshkevich, Т. Цифровая детерминация: могут ли информационные технологии стать осмысленными? [Digital Determination: Can Information Technologies Become Meaningful?]. Vestn. Mosk. Univ. 2021, 20, 123-132. [CrossRef]

37. Vakhstein, V.S. Пересборка повседневности: беспилотники, лифты и проект ПкM-1 [Rebuilding Everyday Life: Drones, Elevators and the PkM-1 Project]. Available online: https://cyberleninka.ru/article/n/peresborka-povsednevnosti-bespilotnikilifty-i-proekt-pkm-1 (accessed on 3 January 2022). (In Russian)

38. Greenfield, P.M. Technology and informal education: What is taught, what is learned. Science 2009, 323, 69-71. [CrossRef] [PubMed]

39. Klinberg, T. The Overflowing Brain: Information Overload and the Limits of Working Memory; Lomonosov: Moscow, Russia, 2010. (In Russian)

40. Zakharova, T.; Sinogina, E.; Smirnova, А. Влияние кибераддикции на характеристики внимания подростков [Суber Addiction and Its Influence on Teenagers' Concentration]. Available online: https:/ / cyberleninka.ru/article/n/vliyanie-kiberaddiktsii-naharakteristiki-vnimaniya-podrostkov / viewer (accessed on 21 January 2022). (In Russian)

41. Staritsina, О. Клиповое мышление vs ОбразованиеКто виноват и что делать? [Clip Thinking vs. Education. Who Is to Blame?]. Available online: https:/ / cyberleninka.ru/article/n/klipovoe-myshlenie-vs-obrazovanie-kto-vinovat-i-chto-delat/ viewer (accessed on 23 January 2022). (In Russian)

42. Girenok, F. Клиповое мышление [Clip Thnking]; Prospect: Moscow, Russia, 2015.

43. Krinkin, K.; Shichkina, Y.; Ignatyev, A. Co-evolutionary hybrid intelligence Co-evolutionary hybrid intelligence. In Proceedings of the V Scientific School “Dynamics of Complex Networks and their Applications” (DCNA'2021), Kaliningrad, Russia, 13-15 September 2021; pp. 122-125.

44. Borgest, N.M. Стратегии интеллекта и его онтологии: попытка разобраться [Intelligence Strategies and Its Ontologies: An Attempt to Understand]. Available online: https://www.ontology-of-designing.ru/article/2019_4(34)/2_Borgest.pdf (accessed on 3 January 2022). (In Russian)

45. Finn, V.K. Artificial Intelligence. In Encyclopedia of Epistemology and Philosophy of Science. Available online: https://gufo.me/dict/ epistemology_encyclopedia/искусственный_интеллект (accessed on 4 January 2022). (In Russian)

46. Landgrebe, J.; Smith, B. There Is No Artificial General Intelligence. Available online: https://arxiv.org/pdf/1906.05833.pdf (accessed on 12 December 2021).

47. Purwanto, P.; Kuswandi, K.; Fatmah, F. Interactive Applications with Artificial Intelligence Applications: The Role of Trust among Users. Foresight STI Gov. 2020, 14, 64-75. [CrossRef]

48. Grimov, О.А. Цифровая реальность: социальная онтология и методология эмпирического изучения [Digital Reality: Social Ontology and Methodology of Empirical Study]. Available online: https:/ / cyberleninka.ru/article/n/tsifrovaya-realnostsotsialnaya-ontologiya-i-metodologiya-empiricheskogo-izucheniya/viewer (accessed on 3 January 2022). (In Russian)

49. Floridi, L. A Proxy Culture. Philos. Technol. 2015, 28, 487-490. [CrossRef]

50. Burtsev, M.; Logacheva, V. Conversational Intelligence Challenge: Accelerating Research with Crowd Science and Open Source. AI Mag. 2020, 41, 18-27. [CrossRef] 
51. DeepPavlov Library. Available online: https://mipt.ru/science/labs/laboratoriya-neyronnykh-sistem-i-glubokogo-obucheniya/ projects / DeepPavlov+Library (accessed on 23 December 2021).

52. Strong Artificial Intelligence. Approaching the Supermind [Сильный искусственный интеллект. На подступах к сверхразуму]; Potapov, A., Ed.; Alpina Publisher: Moscow, Russia, 2021. (In Russian)

53. Decree of the President of the Russian Federation of 10.10.2019 No. 490. On the Development of Artificial Intelligence in the Russian Federation. Available online: http://www.kremlin.ru/acts/bank/44731/page/1 (accessed on 4 January 2022). (In Russian)

54. La Fors, K.; Custers, B.; Keymolen, E. Reassessing values for emerging big data technologies: Integrating design-based and application-based approaches. Ethics Inf. Technol. 2019, 21, 209-226. [CrossRef]

55. Baum, S.D. Social choice ethics in artificial intelligence. AI Soc. 2020, 35, 165-176. [CrossRef]

56. Karpov, V.; Gotovtsev, P.; Royzerson, G. K вопросу об этике и системах искусственного интеллекта [Ethics and AI Systems]. Available online: https:/ / cyberleninka.ru/article/n/k-voprosu-ob-etike-i-sistemah-iskusstvennogo-intellekta/viewer (accessed on 24 January 2022). (In Russian)

57. Levenchuk, A.I. Системное мышление [System Thinking]; Project “Balovstvo"; Toliman: Boston, MA, USA; Uldingen, Germany; Kiev, Ukraine, 2019.

58. Harari, Y.N. Homo Deus. A Brief History of Tomorrow; HarperCollins Publishers: New York, NY, USA, 2017.

59. Leshkevich, T.; Motozhanets, A. Worldview through the Prism of Personal Life-Meaning Orientations. Philosophia 2021, 49, 1619-1629. [CrossRef]

60. Asadullaev, R.; Nemirovski, G.; Sitnikova, M.; Chumakov, Y.; Kononov, V.; Ananeva, M. An approach for reliable diagnostics of pathological Internet use using EEG data and artificial intelligence. In Proceedings of the III International Conference "Neurotechnologies and Neurointerfaces" (CNN'2021), Kaliningrad, Russia, 13-15 September 2021; pp. 12-16.

61. Shnurenko, I. Искусственный интеллект на грани нервного срыва [Artificial Intelligence on the Verge of a Nervous Breakdown]. Available online: https:/ / expert.ru/expert/2019/01/iskusstvennyij-intellekt-na-grani-nervnogo-sryiva/ (accessed on 4 January 2022). (In Russian)

62. Zednik, C. Solving the Black Box Problem: A Normative Framework for Explainable Artificial Intelligence. Philos. Technol. 2021, 34, 265-288. [CrossRef]

63. Barrat, J. Our Final Invention: Artificial Intelligence and the End of the Human Era; Thomas Dunne Books: New York, NY, USA, 2013.

64. Cycleback, D. Philosophy of Artificial Intelligence: A Critique of the Mechanistic Theory of Mind; Universal-Publishers: Boca Raton, FL, USA, 2009.

65. Latypova, A.R. Между мутацией и глитчем: цифровая эволюция медиа [Between Mutation and Glitch: Digital Evolution of Media]. Available online: https:/ / cyberleninka.ru/article/n/mezhdu-mutatsiey-i-glitchem-tsifrovaya-evolyutsiya-media/ viewer (accessed on 4 January 2022). (In Russian)

66. Wiltshire, A. How Developers Really Deal with Bugs. Available online: https://www.eurogamer.net/articles/2017-07-19-a-devseye-view-of-bugs (accessed on 21 November 2021).

67. Lehman, J.; Clune, J.; Misevic, J. The Surprising Creativity of Digital Evolution. Available online: https: / www.researchgate.net/ publication/326546430_The_Surprising_Creativity_of_Digital_Evolution (accessed on 21 November 2021).

68. Pashentsev, E.N. Злонамеренное использование искусственного интеллекта: новые угрозы для международной информационно-психологической безопасности и пути их нейтрализации [Malicious Use of Artificial Intelligence: New Threats for International Information and Psychological Safety and the Ways of THEIR neutralization]. Available online: https://cyberleninka.ru/article/n/zlonamerennoe-ispolzovanie-iskusstvennogo-intellekta-novye-ugrozy-dlyamezhdunarodnoy-informatsionno-psihologicheskoy-bezopasnosti/viewer (accessed on 4 January 2022). (In Russian)

69. Weizsäcker Von, E.U.; Wijkman, A. Come On! Capitalism, Short-Termism, Population, and the Destruction of the Planet; Springer: New York, NY, USA, 2018.

70. Rieu, A.M. The Epistemological and Philosophical Situation of Mind Techno-Science. Available online: https://www.researchgate. net/publication/281794338_The_epistemological_and_philosophical_situation_of_Mind_Techno-Science (accessed on 21 December 2021).

71. Kaku, M. Future of the Mind: The Scientific Quest to Understand, Enhance, and Empower the Mind; Doubleday: New York, NY, USA, 2014.

72. Clark, A. Natural-Born Cyborgs: Minds, Technologies, and the Future of Human Intelligence; Oxford University Press: Oxford, UK, 2004. 